CLINICAL STUDY

\title{
Rosiglitazone treatment increases plasma levels of adiponectin and decreases levels of resistin in overweight women with PCOS: a randomized placebo-controlled study
}

\author{
A Majuri, M Santaniemi ${ }^{1}$, K Rautio, A Kunnari ${ }^{1}$, J Vartiainen ${ }^{1}$, A Ruokonen ${ }^{2}$, Y A Kesäniemi ${ }^{1}$, J S Tapanainen, \\ O Ukkola ${ }^{1}$ and L Morin-Papunen \\ Departments of Obstetrics and Gynaecology, ${ }^{1}$ Internal Medicine and ${ }^{2}$ Clinical Chemistry, University Hospital of Oulu, PO Box 24, 90029 Oulu, Finland \\ (Correspondence should be addressed to L Morin-Papunen; Email: Imp@cc.oulu.fi)
}

\begin{abstract}
Objective: Abdominal obesity, insulin resistance and compensatory hyperinsulinaemia play a central role in the pathogenesis of the polycystic ovary syndrome (PCOS). Abdominal adipose tissue is a source of adipokines, such as adiponectin and resistin, both of which may be involved in the development of insulin resistance and chronic inflammation in PCOS. Ghrelin, an important regulatory peptide of food intake, may also play a role in metabolic disturbances related to PCOS.

The aim of this study was to examine the effects of 4 months of treatment with the insulin sensitizer rosiglitazone on plasma adiponectin, resistin and ghrelin levels in overweight women with PCOS.

Design: A randomised placebo-controlled study.

Methods: Thirty overweight/obese women with PCOS (body mass index $>25 \mathrm{~kg} / \mathrm{m}^{2}$, mean age $29.1 \pm$ 1.2 (s.E.м.) years) were randomly allocated to either rosiglitazone (Avandia, $4 \mathrm{mg}$ twice a day) or placebo treatment. Plasma levels of adiponectin, resistin and ghrelin and their correlation to serum levels of insulin, C-peptide and steroid hormones, and insulin sensitivity (euglycaemic hyperinsulinaemic clamp) were assessed.

Results: Adiponectin and ghrelin levels correlated significantly with most metabolic markers of insulin resistance and with serum levels of DHEA and 17-hydroxyprogesterone. Plasma levels of adiponectin increased from $9.26 \pm 0.90$ (s.e.m.) to $22.22 \pm 3.66 \mu \mathrm{g} / \mathrm{ml}(P<0.001)$ and those of resistin decreased from $12.57 \pm 1.63$ to $9.21 \pm 0.53 \mathrm{ng} / \mathrm{ml}(P=0.009)$ at 4 months of treatment, but plasma ghrelin levels did not change.

Conclusions: Rosiglitazone had beneficial effects on serum levels of adiponectin and resistin, suggesting that these adipocytokines may contribute to the improvement in insulin sensitivity observed during the treatment.
\end{abstract}

European Journal of Endocrinology $156263-269$

\section{Introduction}

Abdominal obesity, insulin resistance and compensatory hyperinsulinaemia play a central role in the pathogenesis of polycystic ovary syndrome (PCOS), the most common endocrine disorder and cause of anovulatory infertility in women $(1,2)$. Abdominal adiposity per se is a specific and independent risk factor as regards insulin resistance, cardiovascular disease (3-5), glucose intolerance and type 2 diabetes mellitus $(6,7)$. Moreover, adipose tissue is a source of free fatty acids (FFAs) and adipokines, such as adiponectin and resistin (5).

Adiponectin is particularly expressed in adipose tissue (8), and it may have a role in preventing the development of insulin resistance $(9,10)$. The production of adiponectin is decreased in obesity $(8,9)$, and its plasma levels have been shown to correlate negatively with waist-to-hip ratio (WHR, 11) and body mass index (BMI, 8). Decreased plasma levels of adiponectin have been observed in subjects with type 2 diabetes mellitus and coronary artery disease (12), and in women with PCOS (13-16).

The insulin sensitizer rosiglitazone, one of the thiazolidinediones (TZDs), activates peroxisome proliferator-activated receptor- $\gamma$ (PPAR $\gamma$ ), an adipocyte transcription factor. This stimulates adipocyte differentiation to adipocytes in which adiponectin is secreted (17-20). Adiponectin improves glucose transport into cells and insulin sensitivity (21). The TZDs also inhibit inflammatory cytokine production and thereby the development of atherosclerosis (22). The beneficial effect of rosiglitazone on adiponectin secretion and insulin sensitivity has been demonstrated in subjects with type 2 diabetes mellitus and with impaired glucose tolerance $(23,24)$.

Another adipokine, resistin, is expressed in macrophages and to a lesser extent in mature adipocytes in 
humans (25). The results of some studies have suggested that elevated resistin levels may be associated with insulin resistance in diabetic subjects $(26,27)$ and with chronic inflammation, independently of obesity (28), and could be predictive as regards the development of cardiovascular disease (29). Increased plasma resistin concentrations have also been found in women with PCOS compared with women without the syndrome in some $(14,30)$, but not in all studies (31-33). Rosiglitazone treatment has been shown to decrease resistin plasma levels among HIV-infected subjects with insulin resistance (34) and in patients with diabetes mellitus (35), and has been suggested to have a direct reducing effect on resistin through macrophage PPAR $\gamma$ activation in humans $(36,37)$.

Ghrelin, a peptide produced primarily by the endocrine cells in the stomach (38), is an endogenous ligand of the growth hormone $(\mathrm{GH})$ secretagogue receptor and stimulates $\mathrm{GH}$ secretion (39). It has been suggested to be an important regulatory peptide in food intake, long-term body weight regulation, glucose metabolism and ovarian function $(39,40)$. Low serum ghrelin levels have been shown to be associated with abdominal obesity, hyperinsulinaemia and insulin resistance in type 2 diabetic patients $(41,42)$ and to be decreased in women with PCOS (43).

The aim of the present study was to investigate the effects of rosiglitazone on adiponectin and resistin as well as on ghrelin levels in PCOS subjects, and to assess the correlations of adiponectin, resistin and ghrelin concentrations with various anthropometric and metabolic variables.

\section{Materials and methods}

\section{Subjects}

The subjects included in this study have participated in our earlier studies on the effects of rosiglitazone on insulin sensitivity, glucose tolerance and hormonal parameters (44), and on low-grade inflammation and liver function in PCOS (45). Thirty women with PCOS $\left(\mathrm{BMI}>5 \mathrm{~kg} / \mathrm{m}^{2}\right.$, mean age $29.1 \pm 1.2$ (s.E.M.) years, range 18-41) were recruited from the Reproductive Endocrine Unit at Oulu University Hospital (44). The criteria for PCOS were defined according to the new consensus criteria (46). Diabetic subjects, subjects who had signs of liver or renal failure or active liver disease (ALT $>2.5 \times$ the upper limit of normal values), smokers, alcohol users and those taking medication known to affect reproductive or metabolic functions within 2 months of the study were excluded. One subject from each group discontinued the study for personal reasons and two became pregnant in the rosiglitazone group. In the rosiglitazone group, 12 women completed the study and 14 in the placebo group.
The study was approved by the Ethics Committee of Oulu University Hospital, and informed written consent was obtained from each subject.

\section{Protocol of the study}

The subjects were randomly and blindly allocated to receive either rosiglitazone (ROSI group; Avandia, GlaxoSmithKline, PA, $4 \mathrm{mg}$ once daily for 2 weeks, then $4 \mathrm{mg}$ twice daily) or placebo (PLA group) for 4 months, as published previously (44). All subjects were examined 1-7 days after spontaneous or progestininduced (oligomenorrhoeic and amenorrhoeic subjects) menstruation before treatment and at 4 months of treatment. They received instructions regarding a weight-maintenance diet throughout the study. The weight of the subjects, fasting glucose, haemoglobin, haematocrit, liver enzymes and urinary pregnancy test results were assessed monthly during the study.

Waist and hip circumferences were measured to the nearest centimetre with a soft tape at the narrowest part of the torso and at the widest part of the gluteal region. Transvaginal ultrasonography, the oral glucose tolerance test (OGTT), the i.v. glucose tolerance test (IVGTT), the euglycaemic hyperinsulinaemic clamp (to determine the level of insulin sensitivity, i.e. whole-body glucose disposal rate, $M$ value) and calorimetry to assess glucose and fat oxidation rates were carried out and blood samples for glucose levels, serum concentrations of insulin, C-peptide, sex hormone-binding globulin (SHBG), C-reactive protein (CRP) and steroid hormones were drawn as described previously (44). The incremental insulin $\left(\mathrm{AUC}_{\text {ins }}\right)$ and glucose $\left(\mathrm{AUC}_{\text {gluc }}\right)$ areas under the curve during the OGTT were calculated by the trapezoidal method. The free androgen index (FAI) was calculated according to the equation: (testosterone $(T) \times 100) /$ SHBG, with $T$ and SHBG expressed in nanomoles per litre.

\section{Assays and calculations}

The samples for blood glucose levels, serum concentrations of insulin, C-peptide, SHBG, CRP and steroid hormones were analysed as previously described (44).

Plasma adiponectin concentrations were measured in triplicate by means of an ELISA devised in our laboratory: monoclonal anti-human adiponectin antibody at $2 \mu \mathrm{g} / \mathrm{ml}$ (R\&D-systems, Cat. MAB10651) was used as a capture antibody and biotinylated monoclonal anti-human adiponectin antibody at $1.5 \mu \mathrm{g} / \mathrm{ml}$ (R\&D-systems, Cat. MAB1065) was used as a detection antibody. For detection of biotin-labelled antibody, we used 1:18 000 diluted alkaline phosphatase-labelled NeutrAvidin (Pierce Cat. 31002) and 30\% Lumiphos530 (Lumigen, Cat. P-501). A standard curve from 1.56 to $60 \mathrm{ng} / \mathrm{ml}$ was prepared from human recombinant adiponectin (Biovendor, Cat. 
RD172023100). Plasma samples were diluted at a ratio of $1: 1000$ and the concentrations were measured in duplicate. The intra-assay coefficient of variation of the method was $11.1 \%$ and the inter-assay variation was 4.5\%. Baseline and post-treatment samples from individual subjects were measured in the same assay.

Plasma resistin levels were measured in duplicate using a commercially available enzyme-linked immunoassay kit (Linco Research Inc., MO, USA; intra- and inter-assay coefficients of variation being 4.5 and $7.4 \%$ respectively) according to the manufacturer's instructions. Baseline and post-treatment samples from individual subjects were measured in the same assay.

Fasting plasma total ghrelin concentrations were measured in duplicate using a commercial RIA (Linco Research, Inc., USA; intra-assay coefficient of variation $2.65 \%$ ). Measurement was carried out according to the manufacturer's instructions.

\section{Statistical methods}

The paired $t$-test was used to compare the changes of clinical, metabolic and hormonal parameters within the ROSI and PLA groups during the treatment. Wilcoxon's unpaired test was used for variables with persisting skewed distribution after log transformation. For comparison of the ROSI and PLA groups before the treatment, Student's two-tailed t-test was used for normally distributed variables. The Mann-Whitney U-test was used for variables with persisting skewed distribution after log transformation. The comparison of changes after treatment between rosiglitazone and placebo groups was assessed by ANOVA for repeated measures.

Analysis of correlation between parameters was performed by calculating Pearson's bivariate correlation coefficient.

\section{Results}

\section{Baseline characteristics}

All the subjects of the study had polycystic ovaries at echography. In the ROSI group, seven subjects displayed both oligo-/amenorrhea and hirsutism, two had oligomenorrhea only and three hirsutism only. In the PLA group, all the subjects were hirsute and ten displayed also oligo-/amenorrhea.

At baseline, the ROSI and PLA groups did not differ with respect to age $(30.1 \pm 2.1$ in the ROSI group vs $27.1 \pm 1.1$ years in the PLA group), BMI $(33.7 \pm 1.0$ in the ROSI group vs $33.6 \pm 1.0 \mathrm{~kg} / \mathrm{m}^{2}$ in the PLA group), WHR $(0.87 \pm 0.01$ in the ROSI group vs $0.87 \pm 0.01$ in the PLA group), hirsutism score $(9.8 \pm 1.5$ in the ROSI group vs $8.8 \pm 0.9$ in the PLA group) and menstrual cycle. The baseline hormonal and metabolic parameters have been published earlier (44).
Adiponectin and resistin levels were similar in the ROSI and PLA groups at baseline (Fig. 1). The significant correlations of adiponectin, resistin and ghrelin with anthropometric and metabolic variables are presented in Table 1. Adiponectin and ghrelin concentrations correlated significantly with most metabolic markers of insulin resistance and with the levels of some androgens such as DHEA and 17-OHP, but no significant correlation was found with lipid levels or inflammatory parameters (Table 1).

\section{Changes during rosiglitazone treatment}

Plasma levels of adiponectin increased (from 9.26 \pm 0.90 (s.е.м.) to $22.22 \pm 3.66 \mu \mathrm{g} / \mathrm{ml}, \quad P<0.001)$ and plasma resistin levels decreased (from $12.57 \pm 1.63$ to $9.21 \pm 0.53 \mathrm{ng} / \mathrm{ml}, P=0.009)$ significantly during the 4 months of treatment with rosiglitazone. During the 4 months' treatment with rosiglitazone, the changes in serum levels of adiponectin $(P<0.001)$ and resistin $(P=0.03)$ were significant compared with the changes
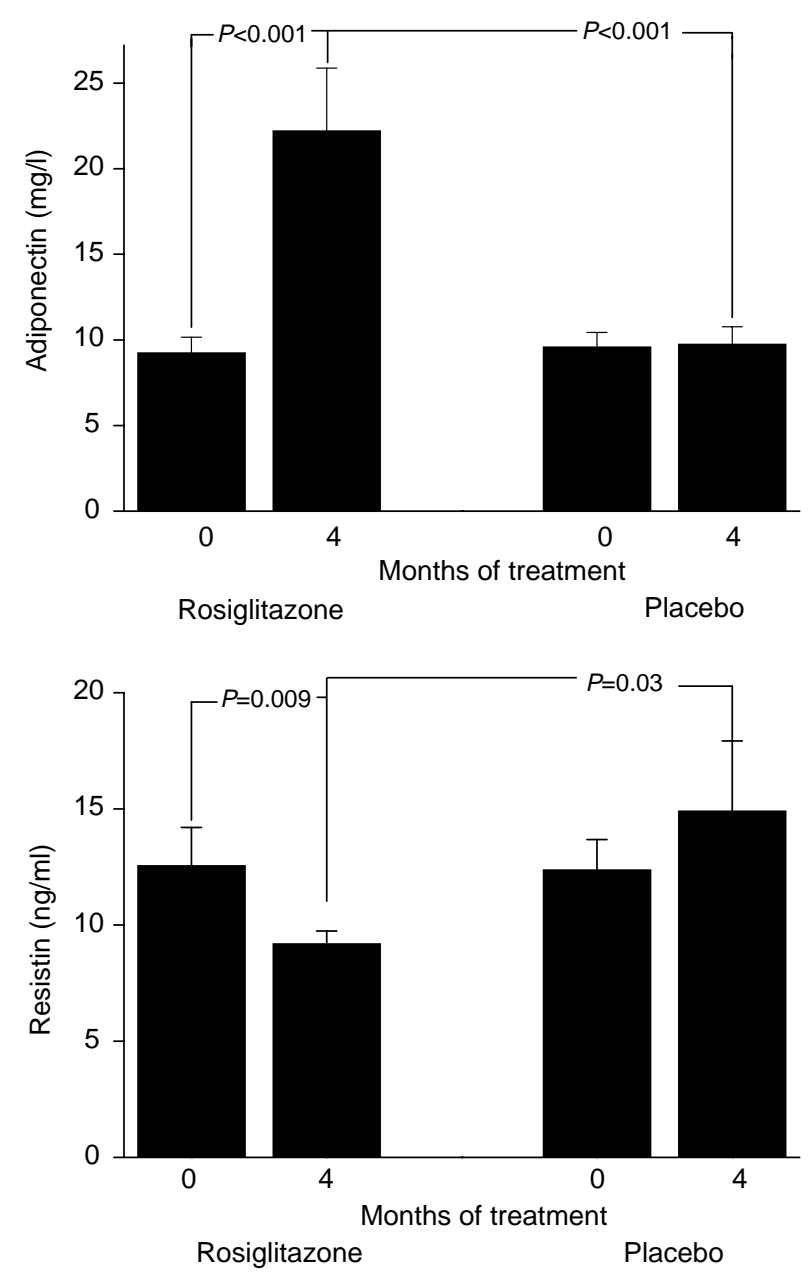

Figure 1 Plasma levels of adiponectin and resistin before and at 4 months of rosiglitazone and placebo treatment. 
Table 1 Significant correlations between adiponectin, resistin and ghrelin with anthropometric metabolic and hormonal parameters at baseline in the whole study group.

\begin{tabular}{|c|c|c|c|}
\hline No. of subjects & $\begin{array}{c}\text { Adiponectin } \\
\qquad N=30\end{array}$ & $\begin{array}{c}\text { Resistin } \\
N=30\end{array}$ & $\begin{array}{c}\text { Ghrelin } \\
N=30\end{array}$ \\
\hline BMI & $\begin{array}{r}P=0.008 \\
r=-0.521\end{array}$ & $\begin{aligned} P & =0.700 \\
r & =0.081\end{aligned}$ & $\begin{array}{r}P=0.298 \\
r=-0.221\end{array}$ \\
\hline Waist & $\begin{array}{r}P=0.228 \\
r=-0.250\end{array}$ & $\begin{array}{r}P=0.835 \\
r=-0.044\end{array}$ & $\begin{array}{r}P=0.050 \\
r=-0.397\end{array}$ \\
\hline Hip & $\begin{array}{r}P=0.028 \\
r=-0.440\end{array}$ & $\begin{aligned} P & =0.941 \\
r & =0.016\end{aligned}$ & $\begin{array}{r}P=0.820 \\
r=-0.048\end{array}$ \\
\hline WHR & $\begin{array}{r}P=0.932 \\
r=-0.018\end{array}$ & $\begin{array}{r}P=0.867 \\
r=-0.035\end{array}$ & $\begin{array}{r}P=0.026 \\
r=-0.444\end{array}$ \\
\hline Fasting insulin & $\begin{array}{r}P=0.002 \\
r=-0.587\end{array}$ & $\begin{aligned} P & =0.208 \\
r & =0.261\end{aligned}$ & $\begin{array}{r}P=0.055 \\
r=-0.388\end{array}$ \\
\hline AUC-insulin & $\begin{array}{r}P=0.353 \\
r=-0.203\end{array}$ & $\begin{array}{r}P=0.781 \\
r=-0.061\end{array}$ & $\begin{array}{r}P=0.001 \\
r=-0.681\end{array}$ \\
\hline C peptide & $\begin{array}{r}P=0.006 \\
r=-0.535\end{array}$ & $\begin{aligned} P & =0.049 \\
r & =0.397\end{aligned}$ & $\begin{array}{r}P=0.264 \\
r=-0.232\end{array}$ \\
\hline$M$ value & $\begin{array}{r}P=0.031 \\
r=-0.433\end{array}$ & $\begin{array}{r}P=0.234 \\
r=-0.247\end{array}$ & $\begin{aligned} P & =0.023 \\
r & =0.453\end{aligned}$ \\
\hline AUC-glucos & $\begin{array}{r}P=0.208 \\
r=-0.266\end{array}$ & $\begin{aligned} P & =0.392 \\
r & =0.183\end{aligned}$ & $\begin{array}{r}P=0.029 \\
r=-0.447\end{array}$ \\
\hline FAI & $\begin{aligned} P & =0.194 \\
r & =0.269\end{aligned}$ & $\begin{array}{r}P=0.079 \\
r=-0.358\end{array}$ & $\begin{array}{r}P=0.014 \\
r=-0.487\end{array}$ \\
\hline DHEA & $\begin{aligned} P & =0.025 \\
r & =0.448\end{aligned}$ & $\begin{array}{r}P=0.315 \\
r=-0.209\end{array}$ & $\begin{array}{r}P=0.115 \\
r=-0.232\end{array}$ \\
\hline DHEAS & $\begin{aligned} P & =0.077 \\
r & =0.360\end{aligned}$ & $\begin{array}{r}P=0.205 \\
r=-0.263\end{array}$ & $\begin{array}{r}P=0.023 \\
r=-0.453\end{array}$ \\
\hline 17-OHP & $\begin{array}{r}P=0.036 \\
r=0.422\end{array}$ & $\begin{array}{r}P=0.695 \\
r=-0.083\end{array}$ & $\begin{array}{r}P=0.418 \\
r=-0.169\end{array}$ \\
\hline Androstenedione & $\begin{array}{r}P=0.141 \\
r=0.303\end{array}$ & $\begin{array}{r}P=0.404 \\
r=-0.174\end{array}$ & $\begin{array}{r}P=0.051 \\
r=-0.395\end{array}$ \\
\hline Clamp FFA & $\begin{array}{r}P=0.039 \\
r=-0.416\end{array}$ & $\begin{aligned} P & =0.013 \\
r & =0.492\end{aligned}$ & $\begin{array}{r}P=0.152 \\
r=-0.295\end{array}$ \\
\hline Glucose non-oxidation & $\begin{aligned} P & =0.004 \\
r & =0.560\end{aligned}$ & $\begin{array}{r}P=0.179 \\
r=-0.278\end{array}$ & $\begin{array}{r}P=0.049 \\
r=0.398\end{array}$ \\
\hline
\end{tabular}

during placebo treatment. Treatment with placebo did not affect adiponectin and resistin levels (Fig. 1).

The increase in adiponectin levels during the treatment correlated significantly with the decrease in the serum FFA levels during the euglycaemic clamp $(P=0.017 ; r=-0.76$, Table 2 and Fig. 2$)$. The other correlations between the changes in adiponectin and resistin levels and those in metabolic and endocrine variables during the rosiglitazone treatment did not reach statistical significance (Table 2).

Plasma ghrelin levels did not change significantly during rosiglitazone $(744.2 \pm 106.6$ vs $780.9 \pm$ $52.1 \mathrm{pg} / \mathrm{ml})$ or placebo treatment $(969.6 \pm 124.1$ vs $1287.0 \pm 197.7 \mathrm{pg} / \mathrm{ml})$.

\section{Discussion}

The present results demonstrated that treatment with rosiglitazone had a significant effect on plasma adipokine levels, increasing plasma adiponectin and decreasing resistin levels in overweight women with PCOS. In contrast, no change was observed in the plasma ghrelin levels.
Table 2 Correlations between the changes in adiponectin and resistin levels with the changes in anthropometric, metabolic and hormonal parameters during the rosiglitazone treatment.

\begin{tabular}{|c|c|c|}
\hline & $\Delta$ Adiponectin & $\Delta$ Resistin \\
\hline \multirow[t]{2}{*}{$\Delta \mathrm{BMI}$} & $P=0.44$ & $P=0.52$ \\
\hline & $r=0.27$ & $r=-0.23$ \\
\hline \multirow[t]{2}{*}{$\Delta \mathrm{WHR}$} & $P=0.80$ & $P=0.85$ \\
\hline & $r=-0.06$ & $r=-0.07$ \\
\hline \multirow[t]{2}{*}{$\Delta$ Fasting insulin } & $P=0.29$ & $P=0.65$ \\
\hline & $r=-0.36$ & $r=0.16$ \\
\hline \multirow[t]{2}{*}{$\Delta A U C$ insulin } & $P=0.08$ & $P=0.58$ \\
\hline & $r=-0.65$ & $r=-0.23$ \\
\hline \multirow[t]{2}{*}{$\Delta M$ value } & $P=0.44$ & $P=0.85$ \\
\hline & $r=-0.29$ & $r=-0.07$ \\
\hline \multirow[t]{2}{*}{$\Delta$ Fasting glucose } & $P=0.65$ & $P=0.54$ \\
\hline & $r=-0.16$ & $r=0.22$ \\
\hline \multirow{2}{*}{$\Delta \mathrm{AUC}$ glucose } & $P=0.47$ & $P=0.18$ \\
\hline & $r=-0.26$ & $r=0.46$ \\
\hline \multirow[t]{2}{*}{$\Delta \mathrm{CRP}$} & $P=0.98$ & $P=0.06$ \\
\hline & $r=-0.008$ & $r=0.61$ \\
\hline \multirow[t]{2}{*}{$\Delta \mathrm{SHBG}$} & $P=0.51$ & $P=0.57$ \\
\hline & $r=0.24$ & $r=-0.20$ \\
\hline \multirow[t]{2}{*}{$\Delta$ Testosterone } & $P=0.09$ & $P=0.72$ \\
\hline & $r=0.56$ & $r=0.13$ \\
\hline \multirow[t]{2}{*}{$\Delta$ clFFA } & $P=0.017$ & $P=0.98$ \\
\hline & $r=-0.76$ & $r=-0.01$ \\
\hline \multirow[t]{2}{*}{$\Delta \mathrm{fFFA}$} & $P=0.24$ & $P=0.09$ \\
\hline & $r=0.43$ & $r=0.60$ \\
\hline
\end{tabular}

$\Delta$, Change during the treatment; BMI, body mass index; WHR, waist-hipratio; AUC, area under the curve during the oral glucose tolerance test; CRP, C-reactive protein; SHBG, sex hormone-binding globulin; FFA, fasting serum levels of fatty free acids; cIFFA, serum levels of fatty free acids during the clamp.

At baseline, plasma levels of adiponectin correlated negatively with BMI, serum insulin and C-peptide levels, and positively with the whole body glucose disposal rate ( $M$ value) and non-oxidative glucose disposal, but not with oxidative glucose disposal before or during the clamp. These findings are in line with the results of earlier studies (47-49) suggesting that adiponectin is strongly associated with insulin sensitivity in humans. More

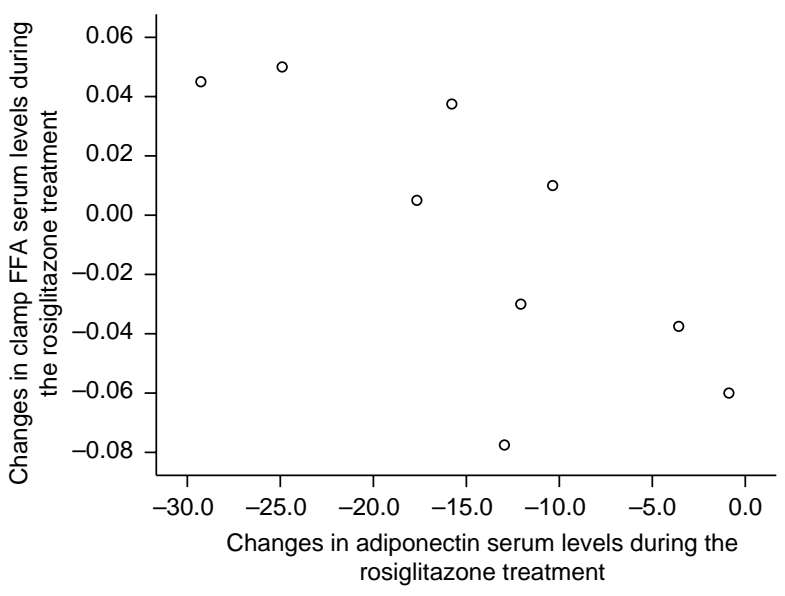

Figure 2 Correlation between the changes in serum fatty free acid levels during the clamp (clamp FFA) and the changes in adiponectin levels during the rosiglitazone treatment $(P=0.017, r=-0.76)$. 
specifically, adiponectin could control insulin sensitivity mainly by modulating non-oxidative glucose disposal, i.e. the glycogen synthesis pathway in human skeletal muscle (50). It is interesting to note that plasma adiponectin levels correlated significantly with FFA levels at baseline, and during rosiglitazone treatment, the changes of adiponectin and clamp FFA concentrations were significantly and negatively associated. These findings suggest an active role of adiponectin not only in the improvement of insulin sensitivity during rosiglitazone treatment, but also in the regulation of fat tissue metabolism.

Treatment with rosiglitazone increased plasma adiponectin levels more than twofold in PCOS subjects. Similar changes in adiponectin levels during rosiglitazone treatment have been observed in patients with impaired glucose tolerance (23), type 2 diabetes $(24,50)$ and in one non-placebo-controlled study in women with PCOS (13). In a previous study, we demonstrated that the well-known risk factors for coronary heart disease and type 2 diabetes, serum levels of CRP and white blood cell count (51-55), decreased during rosiglitazone treatment (Rautio et al. in press). Thus, the present findings further support a beneficial effect of rosiglitazone on metabolic and cardiovascular risk factors in PCOS.

Rosiglitazone treatment significantly decreased plasma resistin levels in overweight women with PCOS. A similar effect of rosiglitazone has been reported in type 2 diabetic patients (35) and in HIV-positive subjects with insulin resistance (34). The role of resistin in humans is not well understood. It has been found to be correlated with insulin resistance (26) and to have proinflammatory regulatory properties in human monocytes in vitro (56) and in diabetic patients (28). Furthermore, elevated levels of resistin have been associated with coronary atherosclerosis (29). The present data suggest that rosiglitazone, by decreasing plasma resistin levels, may have beneficial effects in the prevention of atherosclerosis and cardiovascular diseases in women with PCOS.

Plasma ghrelin concentrations did not change during rosiglitazone treatment, which could be a result of the relatively low number of subjects in the rosiglitazone group and the large variation of ghrelin levels between the subjects. However, in line with the results of previous studies $(42,57-59)$, the baseline plasma levels of ghrelin were significantly associated with the key parameters related to abdominal obesity and insulin resistance, such as $\mathrm{WHR}, \mathrm{AUC}_{\mathrm{ins}}, \mathrm{AUC}_{\text {gluc }}$ and $M$ value, the best indicator of insulin sensitivity (60). Plasma levels of ghrelin correlated negatively with androgen levels and the FAI, suggesting that ghrelin may also be related to hyperandrogenism in PCOS.

In conclusion, rosiglitazone treatment increased plasma levels of adiponectin and decreased plasma levels of resistin in overweight women with PCOS, suggesting that these adipocytokines may contribute to the improvement in insulin sensitivity observed during rosiglitazone treatment.

\section{Acknowledgements}

Grants: This work was supported by grants from the Academy of Finland, the Sigrid Jusélius Foundation and Oulu University Hospital.

\section{References}

1 Dunaif A \& Thomas A. Current concepts in the polycystic ovary syndrome. Annual Review of Medicine 200152 401-419.

2 Franks S. Polycystic ovary syndrome. New England Journal of Medicine 1995333 853-861.

3 Kissebah AH, Vydelingum N, Murray R, Evans DJ, Hartz AJ, Kalkhoff RK \& Adams PW. Relation of body fat distribution to metabolic complications of obesity. Journal of Clinical Endocrinology and Metabolism $1982 \mathbf{5 4} 254-260$.

4 Lapidus L, Bengtsson C, Larsson B, Pennert K, Rybo E \& Sjostrom L. Distribution of adipose tissue and risk of cardiovascular disease and death: a 12 year follow up of participants in the population study of women in Gothenburg, Sweden. British Medical Journal 1984289 1257-1261.

5 Lebovitz HE \& Banerji MA. Point: visceral adiposity is causally related to insulin resistance. Diabetes Care 200528 2322-2325.

6 Hayashi T, Boyko EJ, Leonetti DL, McNeely MJ, Newell-Morris L, Kahn SE \& Fujimoto WY. Visceral adiposity and the risk of impaired glucose tolerance: a prospective study among Japanese Americans. Diabetes Care 200326 650-655.

7 Boyko EJ, Fujimoto WY, Leonetti DL \& Newell-Morris L. Visceral adiposity and risk of type 2 diabetes: a prospective study among Japanese Americans. Diabetes Care 200023 465-471.

8 Arita Y, Kihara S, Ouchi N, Takahashi M, Maeda K, Miyagawa J, hotta K, Shimomura I \& Nakamura T. Paradoxical decrease of an adipose-specific protein, adiponectin, in obesity. Biochemical and Biophysical Research Communications 1999257 79-83.

9 Weyer C, Funahashi T, Tanaka S, Hotta K, Matsuzawa Y, Pratley RE \& Tataranni PA. Hypoadiponectinemia in obesity and type 2 diabetes: close association with insulin resistance and hyperinsulinemia. Journal of Clinical Endocrinology and Metabolism 200186 1930-1935.

10 Stefan N, Vozarova B, Funahashi T, Matsuzawa Y, Weyer C, Lindsay RS, Youngren JF, Havel PJ, Pratley RE, Bogardus C \& Tataranni PA. Plasma adiponectin concentration is associated with skeletal muscle insulin receptor tyrosine phosphorylation, and low plasma concentration precedes a decrease in whole-body insulin sensitivity in humans. Diabetes 200251 1884-1888.

11 Vilarrasa N, Vendrell J, Maravall J, Broch M, Estepa A, Megia A, Soler J, Simón I, Richart C \& Gómez JM. Distribution and determinants of adiponectin, resistin and ghrelin in a randomly selected healthy population. Clinical Endocrinology 200563 329-335.

12 Hotta K, Funahashi T, Arita Y, Takahashi M, Matsuda M, Okamoto Y, Iwahashi H, Kuriyama H, Ouchi N, Maeda K, Nishida M, Kihara S, Sakai N, Nakajima T, Hasegawa K, Muraguchi M, Ohmoto Y, Nakamura T, Yamashita S, Hanafusa T \& Matsuzawa Y. Plasma concentrations of a novel, adipose-specific protein, adiponectin, in type 2 diabetic patients. Arteriosclerosis, Thrombosis, and Vascular Biology 200020 1595-1599.

13 Sepilian V \& Nagamani M. Adiponectin levels in women with polycystic ovary syndrome and severe insulin resistance. Journal of the Society for Gynecologic Investigation 200512 129-134.

14 Carmina E, Orio F, Palomba S, Cascella T, Longo Ra, Colao AM, Lombardi G \& Lobo RA. Evidence for altered adipocyte function in polycystic ovary syndrome. European Journal of Endocrinology 2005 152 389-394.

15 Vrbikova J, Dvorakova K, Hill M, Vcelak J, Stanicka S, Vankova M, Sramkova D, Vondra K, Bendlova B \& Starka L. Determinants of circulating adiponectin in women with polycystic ovary syndrome. Gynecologic Obstetric Investigation 200560 155-161. 
16 Ardawi MS \& Rouzi AA. Plasma adiponectin and insulin resistance in women with polycystic ovary syndrome. Fertility and Sterility 200583 1708-1716.

17 Yamauchi T, Kamon J, Waki H, Murakami K, Motojima K, Komeda K, Ide T, Kubota N, Terauchi Y, Tobe K, Miki H, Tsuchida A, Akanuma Y, Nagai R, Kimura S \& Kadowaki T. The mechanisms by which both heterozygous peroxisome proliferatoractivated receptor gamma (PPARgamma) deficiency and PPARgamma agonist improve insulin resistance. Journal of Biological Chemistry $200127641245-41254$.

18 Maeda N, Takahashi M, Funahashi T, Kihara S, Nishizawa $\mathrm{H}$, Kishida K, Nagaretani H, Matsuda M, Komuro R, Ouchi N, Kuriyama H, Hotta K, Nakamura T, Shimomura I \& Matsuzawa Y. PPARgamma ligands increase expression and plasma concentrations of adiponectin, an adipose-derived protein. Diabetes 2001 50 2094-2099.

19 Walczak R \& Tontonoz P. PPARadigms and PPARadoxes: expanding roles for PPARgamma in the control of lipid metabolism. Journal of Lipid Research $2002 \mathbf{4 3} 177-186$.

20 Korner A, Wabitsch M, Seidel B, Fisher-Posovszky P, Berthold A, Stumvoll M, Blüher M, Kratzsch J \& Kiess W. Adiponectin expression in humans is dependent on differentiation of adipocytes and down-regulated by humoral serum components of high molecular weight. Biochemical and Biophysical Research Communications $2005337540-550$.

$21 \mathrm{Fu} \mathrm{Y,} \mathrm{Luo} \mathrm{N,} \mathrm{Klein} \mathrm{RL} \mathrm{\&} \mathrm{Garvey} \mathrm{WT.} \mathrm{Adiponectin} \mathrm{promotes}$ adipocyte differentiation, insulin sensitivity, and lipid accumulation. Journal of Lipid Research 200546 1369-1379.

22 Desvergne B \& Wahli W. Peroxisome proliferator-activated receptors: nuclear control of metabolism. Endocrine Reviews 199920 649-688.

23 Hung YJ, Lin SH, Pei D, Kuo SW, Hsieh CH, He CT, Lee CH, Fan SC \& Sheu WHH. Rosiglitazone improves insulin sensitivity in nonobese subjects with impaired glucose tolerance: the role of adiponectin and C-reactive protein. Metabolism, Clinical and Experimental $2006 \mathbf{5 5} 439-444$.

24 Osei K, Gaillard T, Kaplow J, Bullock M \& Schuster D. Effects of rosglitazone on plasma adiponectin, insulin sensitivity, and insulin secretion in high-risk African Americans with impaired glucose tolerance test and type 2 diabetes. Metabolism, Clinical and Experimental $2004531552-1557$.

25 Curat CA, Wegner V, Sengenes C, Miranville A, Tonus C, Busse R \& Bouloumié A. Macrophages in human visceral adipose tissue: increased accumulation in obesity and a source of resistin and visfatin. Diabetologia $2006 \mathbf{4 9} 744-747$.

26 Silha JV, Krsek M, Skrha JV, Sucharda P, Nyomba BL \& Murphy LJ. Plasma resistin, adiponectin and leptin levels in lean and obese subjects: correlations with insulin resistance. European Journal of Endocrinology $2003149331-335$.

27 Lu HL, Wang HW, Wen Y, Zhang MX \& Lin HH. Roles of adipocyte derived hormone adiponectin and resistin in insulin resistance of type 2 diabetes. World Journal of Gastroenterology 200612 1747-1751.

28 Shetty GK, Economides PA, Horton ES, Mantzoros CS \& Veves A. Circulating adiponectin and resistin levels in relation to metabolic factors, inflammatory markers, and vascular reactivity in diabetic patients and subjects at risk for diabetes. Diabetes Care 200427 2450-2457.

29 Reilly MP, Lehrke M, Wolfe ML, Rohatgi A, Lazar MA \& Rader DJ. Resistin is an inflammatory marker of atherosclerosis in humans. Circulation $2005111932-939$.

30 Munir I, Yen HW, Baruth T, Tarkowski R, Azziz R, Magoffin DA \& Jakimiuk AJ. Resistin stimulation of 17alpha-hydroxylase activity in ovarian theca cells in vitro: relevance to polycystic ovary syndrome. Journal of Clinical Endocrinology and Metabolism $2005 \mathbf{8}$ 4852-4857.

31 Seow KM, Juan CC, Hsu YP, Ho LT, Wang YY \& Hwang JL. Serum and follicular resistin levels in women with polycystic ovarian syndrome during IVF-stimulated cycles. Human Reproduction 2005 20 117-121.
32 Panidis D, Koliakos G, Kourtis A, Farmakiotis D, Mouslech T \& Rousso D. Serum resistin levels in women with polycystic ovary syndrome. Fertility and Sterility 200481 361-366.

33 Seow KM, Juan CC, Wu LY, Hsu YP, Yang WM, Tsai YL, Hwang JL \& Ho LT. Serum and adipocyte resistin in polycystic ovary syndrome with insulin resistance. Human Reproduction 200419 48-53.

34 Kamin D, Hadigan C, Lehrke M, Mazza S, Lazar MA \& Grinspoon S. Resistin levels in human immunodeficiency virus-infected patients with lipoatrophy decrease in response to rosiglitazone. Journal of Clinical Endocrinology and Metabolism 200590 3423-3426.

35 Jung HS, Youn BS, Cho YM, Yu KY, Park HJ, Shin CS, Kim SY, Lee HK \& Park KS. The effects of rosiglitazone and metformin on the plasma concentrations of resistin in patients with type 2 diabetes mellitus. Metabolism, Clinical and Experimental $2005 \mathbf{5 4}$ 314-320.

36 Patel L, Buckels AC, Kinghorn IJ, Murdock PR, Holbrook JD, Plumpton C, Macphee $\mathrm{CH} \&$ Smith SA. Resistin is expressed in human macrophages and directly regulated by PPAR gamma activators. Biochemical and Biophysical Research Communications $2003300472-476$.

37 Samaha FF, Szapary PO, Iqbal N, Williams MM, Bloedon LT, Kochar A, Wolfe ML \& Rader DJ. Effects of rosiglitazone on lipids, adipokines, and inflammatory markers in nondiabetic patients with low high-density lipoprotein cholesterol and metabolic syndrome. Arteriosclerosis, Thrombosis, and Vascular Biology 2006 26 624-630.

38 Kojima M, Hosoda H, Date Y, Nakazato M, Matsuo H \& Kangawa K. Ghrelin is a growth-hormone-releasing acylated peptide from stomach. Nature $1999 \mathbf{4 0 2} 656-660$.

39 Muccioli G, Tschop M, Papotti M, Deghenghi R, Heiman M \& Ghigo E. Neuroendocrine and peripheral activities of ghrelin: implications in metabolism and obesity. European Journal of Pharmacology $2002 \mathbf{4 4 0} 235-254$.

40 Gaytan F, Barreiro ML, Chopin LK, Herington AC, Morales C. Pinilla L, Casanueva FF, Aguilar E, Diéguez C \& Tena-Sempere M. Immunolocalization of ghrelin and its functional receptor, the type 1a growth hormone secretagogue receptor, in the cyclic human ovary. Journal of Clinical Endocrinology and Metabolism $2003 \mathbf{8 8}$ 879-887.

41 Poykko SM, Kellokoski E, Horkko S, Kauma H, Kesaniemi YA \& Ukkola O. Low plasma ghrelin is associated with insulin resistance, hypertension, and the prevalence of type 2 diabetes. Diabetes 2003 52 2546-2553.

42 Katsuki A, Urakawa H, Gabazza EC, Murashima S, Nakatani K, Togashi K, Yano Y, Adachi Y \& Sumida Y. Circulating levels of active ghrelin is associated with abdominal adiposity, hyperinsulinemia and insulin resistance in patients with type 2 diabetes mellitus. European Journal of Endocrinology $2004151573-577$.

43 Schofl C, Horn R, Schill T, Schlosser HW, Muller MJ \& Brabant G. Circulating ghrelin levels in patients with polycystic ovary syndrome. Journal of Clinical Endocrinology and Metabolism 2002 87 4607-4610.

44 Rautio K, Tapanainen JS, Ruokonen A \& Morin-Papunen LC. Endocrine and metabolic effects of rosiglitazone in overweight women with PCOS: a randomized placebo-controlled study. Human Reproduction 200621 1400-1407.

45 Rautio K, Tapanainen JS, Ruokonen A \& Morin-Papunen LC. Rosiglitazone treatment alleviates inflammation and improves liver function in overweight women with PCOS: a randomized placebo-controlled study. Fertility and Sterlity 200787 202-206.

46 Revised 2003 consensus on diagnostic criteria and long-term health risks related to polycystic ovary syndrome (PCOS). Human Reproduction 200419 41-47.

47 Bacha F, Saad R, Gungor N \& Arslanian SA. Adiponectin in youth: relationship to visceral adiposity, insulin sensitivity, and beta-cell function. Diabetes Care 200427 547-552.

48 Weiss R, Taksali SE, Dufour S, Yeckel CW, Papademetris X, Cline G, Tamborlane WV, Dziura J, Shulman GI \& Caprio S. The 'obese insulin-sensitive' adolescent: importance of adiponectin and lipid partitioning. Journal of Clinical Endocrinology and Metabolism 2005 $903731-3737$ 
49 Yokoyama H, Emoto M, Mori K, Araki T, Teramura M, Koyama H, Shoji T, Inaba $M$ \& Nishizawa Y. Plasma adiponectin level is associated with insulin-stimulated nonoxidative glucose disposal. Journal of Clinical Endocrinology and Metabolism 200691 290-294.

50 Tan GD, Debard C, Funahashi T, Humphreys SM, Matsuzawa Y, Frayn KN, Karpe F \& Vidal H. Changes in adiponectin receptor expression in muscle and adipose tissue of type 2 diabetic patients during rosiglitazone therapy. Diabetologia 2005 48 1585-1589.

51 Ridker PM, Hennekens CH, Buring JE \& Rifai N. C-reactive protein and other markers of inflammation in the prediction of cardiovascular disease in women. New England Journal of Medicine $2000342836-843$.

52 Festa A, D'Agostino R, Howard G, Mykkanen L, Tracy RP \& Haffner SM. Inflammation and microalbuminuria in nondiabetic and type 2 diabetic subjects: the insulin resistance atherosclerosis study. Kidney International 200058 1703-1710.

53 Pradhan AD, Manson JE, Rifai N, Buring JE \& Ridker PM. Creactive protein, interleukin 6 , and risk of developing type 2 diabetes mellitus. Journal of the American Medical Association 2001 286 327-334.

54 Hoffman M, Blum A, Baruch R, Kaplan E \& Benjamin M. Leukocytes and coronary heart disease. Atherosclerosis 2004172 1-6.

55 Pannacciulli N, Giorgino F, Martina RA, Resta O, Giorgino R \& De Pergola G. Effect of family history of type 2 diabetes on white blood cell count in adult women. Obesity Research 200311 1232-1237.
56 Bokarewa M, Nagaev I, Dahlberg L, Smith U \& Tarkowski A. Resistin, an adipokine with potent proinflammatory properties. Journal of Immunology 2005 174 5789-5795.

57 Bacha F \& Arslanian SA. Ghrelin suppression in overweight children: a manifestation of insulin resistance? Journal of Clinical Endocrinology and Metabolism 200590 2725-2730.

58 Pagotto U, Gambineri A, Vicennati V, Heiman ML, Tschop M \& Pasquali R. Plasma ghrelin, obesity, and the polycystic ovary syndrome: correlation with insulin resistance and androgen levels. Journal of Clinical Endocrinology and Metabolism 200287 5625-5629.

59 Panidis D, Farmakiotis D, Koliakos G, Rousso D, Kourtis A, Katsikis I, Asteriadis C, Karayannis V \& Diamanti-Kandarakis E. Comparative study of plasma ghrelin levels in women with polycystic ovary syndrome, in hyperandrogenic women and in normal controls. Human Reproduction $2005202127-2132$.

60 DeFronzo RA, Tobin JD \& Andres R. Glucose clamp technique: a method for quantifying insulin secretion and resistance. American Journal of Physiology 1979237 E214-E223.

Received 1 September 2006

Accepted 8 November 2006 